\title{
EFEKTIVITAS KOMUNIKASI PROSES PEMBELAJARAN JARAK JAUH (DARING)
}

\author{
Eka Widyaningsih \\ Program Studi Arsitektur, Fakultas Sains dan Teknologi, Universitas PGRI Yogyakarta, \\ Jalan IKIP PGRI I Sonosewu No. 117 \\ Sonosewu, Ngestiharjo, Kasihan, Bantul, D.I. Yogyakarta \\ Email: ekawidyaningsih@upy.ac.id
}

\begin{abstract}
Abstrak
Pandemi Covid 19 memaksa untuk meminimalisasi pertemuan secara langsung, dalam bekerja juga dalam proses belajar. Dalam proses pembelajaran jarak jauh banyak kendala yang dihadapi, baik yang bersifat teknis maupun non-teknis. Jaringan internet yang tidak mendukung dan keterbatasan biaya untuk mengakses internet (kuota) menjadi salah satu kendala dalam proses belajar jarak jauh atau daring. Dampak dari kendala tersebut adalah kurang maksimalnya penyampaian dan penerimaan materi pembelajaran. Berdasarkan hal tersebut, maka perlu adanya strategi khusus yang harus dilakukan oleh dosen dan program studi dalam mencapai Capaian Pembelajaran Program Studi dan Capaian Pembelajaran Mata Kuliah. Terutama, untuk mata kuliah yang mengharuskan mahasiswa praktek atau dalam Program Studi Arsitektur lebih dikenal dengan istilah studio. Salah satu strategi yang dapat diterapkan antara lain kolaborasi mata kuliah pada jenjang semester yang sama dan mempunyai output atau Capaian Pembelajaran yang bersinergi. Strategi pembelajaran ini bertujuan untuk memberikan pemahaman materi lebih efektif dan efisien kepada mahasiswa.
\end{abstract}

Kata kunci: pembelajaran, jarak jauh, efektivitas.

\section{Abstract}

Title: Communication Efficacy During Distance Learning Process (Online)

The Coronavirus pandemic has been forcing us to avoid physical contact in the working field and educational institutions. We have to deal with many ostacles in this new learning and working environment, both technical and non-technical. Unstable internet connectivity and the financial challenge to provide online access for students at home are among the fundamental problems caused by this distance learning process. As a consequence of this study, material delivery and student's comprehension are at risk. Based on these facts, lecturers and institutions must have proper/ better planning strategies to increase learning outcomes in an academic program as a whole and each course for more aimed results. In an architecture department, studio courses are essential. One strategy example of dealing with today's situation is a collaboration among 2-3 studio courses on the same level to enhance mutual achievement, creating better synergy between methods. This learning strategy's objective is to make the learning process delivery more efficient and comprehensible to students.

Keywords: learning, distance, effectiveness.

\section{Pendahuluan}

Pandemi Covid 19 menjadikan pola interaksi di masyarakat berubah. Dalam upaya pencegahan menyebarnya Covid 19, protokol kesehatan diberlakukan oleh pemerintah, yaitu mencuci tangan degan sabun dan air yang mengalir, memakai masker dan menjaga jarak. Menjaga jarak atau physical distancing, berarti segala aktivitas 
tatap muka secara langsung sangat terbatas, termasuk proses belajar mengajar. Proses belajar mengajar dilakukan tanpa adanya tatap muka atau pembelajaran jarak jauh atau daring atau online. Pelaksanaan pembelajaran daring banyak kendala yang dihadapi di lapangan. Namun, selain kendala di lapangan, juga ada hal positif yang didapatkan.

Pembelajaran daring juga memiliki kelebihan mampu menumbuhkan kemandirian belajar (self regulated learning). Penggunaan aplikasi online mampu meningkatkan kemandirian belajar (Oktavian et al., 2020). Ketidakhadiran dosen secara langsung atau fisik juga menyebabkan mahasiswa merasa tidak canggung dalam mengutarakan gagasan. Ketiadaan penghambat fisik serta batasan ruang dan waktu menyebabkan peserta didik lebih nyaman dalam berkomunikasi (Sadikin et al., 2020).

Berdasarkan surat edaran Direktur Jenderal Pendidikan Tinggi Republik Indonesia No. 1 Tahun 2020, semua universitas diharuskan mengadakan perkuliahan secara daring atau online (https://covid19.hukumonline.com/wpcontent/uploads/2020/04/surat_edaran direktur_jenderal_pendidikan_tinggi_ $\mathrm{n}$ omor_1_tahun_2020-2.pdf). Maka, berdasarkan surat edaran tersebut, perkuliahan di Universitas PGRI Yogyakarta (UPY) juga dilaksanakan secara daring. Perkuliahan secara daring di UPY diberlakukan pada minggu kedua bulan Maret, yang berarti setelah minggu keempat perkuliahan secara tatap muka.

Bagi tenaga pengajar, daring hanya efektif untuk penugasan, sedangkan untuk membuat peserta didik memahami materi pembelajaran secara daring dinilai sulit. Selain itu, kemampuan teknologi dan ekonomi setiap peserta didik berbeda-beda.
Tidak semua peserta didik memiliki fasilitas yang menunjang kegiatan pembelajaran daring. Koneksi internet yang tidak memadai, perangkat yang tidak mendukung dan kuota internet yang mahal menjadi penghambat pembelajaran daring (Maulana \& Hamidi, 2020).

Beberapa penelitian yang berkaitan dengan pembelajaran jarak jauh sudah banyak dilakukan. Namun, penelitianpenelitian tersebut lebih menitikberatkan pada efektivitas mahasiswa dalam proses belajar mengajar jarak jauh dengan spesifikasi mata kuliah teori, diantaranya adalah penelitian yang dilakukan oleh Oktavian et al., 2020. Penelitian berjudul Efektivitas Pembelajaran Daring Terintegrasi di Era Pendidikan 4.0., yang berfokus pada media pembelajaran. Selain itu, penelitian juga dilakukan oleh Widiyono, 2020, Sadikin et al., 2020, Situru, 2020, yang berfokus pada Jurusan Ilmu Ekonomi dan Sosial.

Sedangkan penelitian yang berkaitan dengan efektivitas pembelajaran jarak jauh dengan fokus mata kuliah pratikum masih sangat jarang dilakukan, apalagi yang berkaitan dengan mata kuliah studio yang ada di Program Studi Arsitektur. Salah satu penelitian yang berkaitan dengan mata kuliah praktikum dilakukan oleh Maulana \& Hamidi, 2020 dengan judul Persepsi Mahasiswa terhadap Pembelajaran Daring pada Mata Kuliah Praktik di Pendidikan Vokasi.

Penelitian ini menitikberatkan pada efektivitas pembelajaran jarak jauh untuk mata kuliah studio dan juga penggabungan pembelajaran pada mata kuliah dalam kondisi pandemi Covid 19. Tujuan penelitian ini adalah untuk mengetahui efektivitas pembelajaran jarak jauh, terutama untuk mata kuliah Studio Arsitektur dan efektivitas 
penggabungan dari mata kuliah yang mempunyai capaian pembelajaran bersinergi.

\section{Metode}

Penelitian ini menggunakan metode deskriptif kualitatif dengan mengambil data melalui kuesioner yang dilakukan secara online menggunakan Google Form. Kuesioner disebarkan terbatas pada mahasiswa Program Studi Arsitektur, Fakultas Sains dan Teknologi, Universitas PGRI Yogyakarta. Kuesioner terbagi menjadi beberapa bagian, yaitu media yang digunakan pada saat pembelajaran daring, efektivitas pelaksanaan pembelajaran daring dan hal yang berkaitan dengan koneksi internet dan kuota. Selain kuesioner, penelitian ini juga melihat hasil dari tugas-tugas mahasiswa selama masa perkuliahan online.

\section{Hasil dan Pembahasan}

Perkuliahan Jarak Jauh atau Online Berdasarkan Persepsi Mahasiswa

Pengambilan data dilakukan dengan pengisian kuesioner secara online oleh mahasiswa Program Studi Arsitektur, Fakultas Sains dan Teknologi, UPY. Kuesioner terbagi menjadi 4 bagian pokok, yaitu: Pengisian Identitas, Media Pembelajaran Daring, Pelaksanaan Pembelajaran Daring dan Jaringan Internet untuk pembelajaran daring di Program Studi Arsitektur, Fakultas Sains dan Teknologi dilaksanakan pada semester ganjil 2020-2021 (Gambar 1).

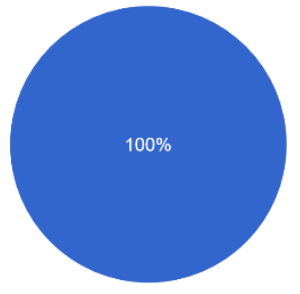

Semester Ganjil

Gambar 1. Diagram pembelajaran daring/ online pada semester ganjil 2020-2021 Sumber: Hasil survey, 2020

Media pembelajaran daring ini menggunakan E-learning UPY dan Google Classroom (Gambar 2). Elearning UPY merupakan media online kampus yang sejak sebelum masa pandemi Covid 19 menjadi media pembelajaran online pendukung pembelajaran tatap muka. Namun, pada saat pemerintah memutuskan untuk bekerja dan belajar dari rumah, E-learning UPY menjadi media online wajib yang harus digunakan oleh dosen.

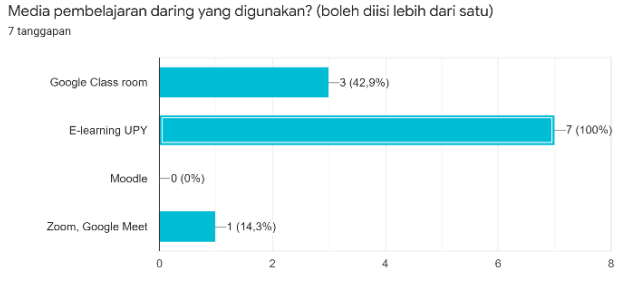

Gambar 2. Jenis media pembelajaran daring yang digunakan Sumber: Hasil survey, 2020

Berdasarkan wawancara dengan tenaga pengajar dan beberapa pertanyaan yang diajukan oleh mahasiswa apabila harus mengumpulkan tugas, kekurangan dari E-learning UPY pada semester genap 2019-2020 adalah kapasitas byte untuk mengupload materi pembelajaran bagi dosen dan tugas bagi mahasiswa masih sangat terbatas. Dengan demikian, salah satu solusi yang dilakukan oleh dosen supaya materi dapat diakses adalah menggunakan tool sinkron Google 
Drive. Kemudian link dari Google Drive tersebut dibagikan lewat $E$ learning.

Pembelajaran daring ini juga menggunakan ragam aktivitas dan tool sinkron pendukung lainnya. Beberapa platfrom yang banyak digunakan di Program Studi Arsitektur, UPY adalah WA Group, Google Meet dan Zoom Cloud Meeting. Penggunaan ragam aktivitas dan tool sinkron ini merupakan upaya untuk memudahkan dalam menyampaikan materi agar lebih jelas dan bisa dipahami oleh mahasiswa. Sedangkan ragam obyek ajar yang digunakan dalam pembelajaran daring di Prodi Arsitektur adalah visual (infografis, gambar, dll.), audio visual, audio dan teks (buku ajar, modul, dll.) (Gambar $3)$.

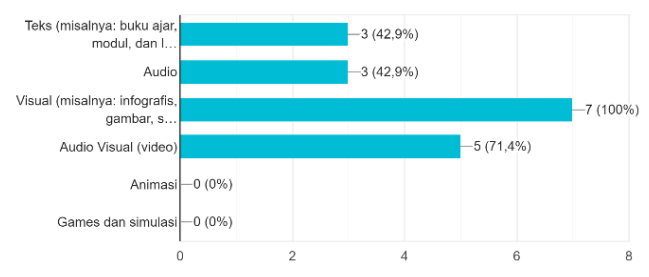

Gambar 3. Ragam obyek pembelajaran daring

Sumber: Hasil survey, 2020

Hasil kuesioner tersebut sesuai dengan penelitian yang dilakukan oleh Jamwal, 2012 dan Kobayashi, 2017 menyatakan bahwa peserta memilih belajar secara interaktif (learning interactive), dimana $80 \%$ menyatakan bahwa email, tugas, presentasi audio, kolaborasi dan video online merupakan media yang paling bermanfaat dalam pembelajaran daring (Oktavian et al., 2020).

Bagian ketiga kuesioner ini membahas tentang pelaksanaan pembelajaran daring. Pertanyaan mendasar dari bagian ini adalah apakah seluruh kegiatan pembelajaran terlaksana dengan baik, terstruktur, sesuai jadwal dan terkoordinasi? Sebagian besar responden menjawab cukup 57,1\%, kurang 28,6\% dan sangat baik 14,3\% (Gambar 4). Berdasarkan hasil tersebut, maka terlihat kesiapan dalam pembelajaran daring belum maksimal.

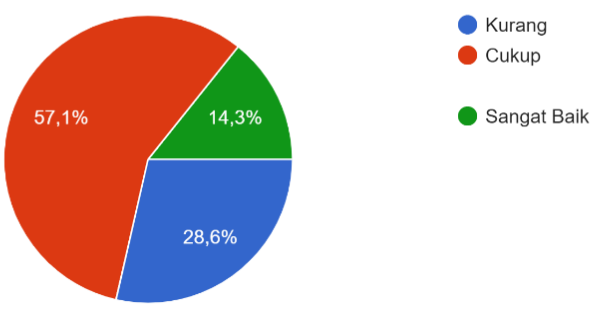

\section{Gambar 4. Pelaksanaan kegiatan pembelajaran daring Sumber: Hasil survey, 2020}

Pembelajaran daring bagi mahasiswa dianggap cukup mudah $(71,4 \%)$ dan mudah $(14,3 \%)$, akan tetapi ada beberapa mahasiswa kesulitan dalam pembelajaran daring (14,3\%) (Gambar $5)$.

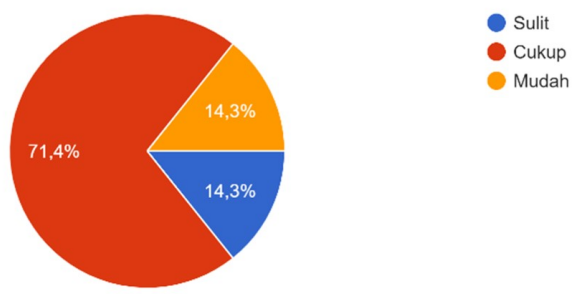

Gambar 5. Tingkat kemudahan/ kesulitan dalam pembelajaran daring Sumber: Hasil survey, 2020

Interaksi dosen dan mahasiswa dalam pembelajaran daring dan tatap muka pasti berbeda. Berdasarkan survey pelaksanaan pembelajaran daring, interaksi dosen dan mahasiswa (Gambar 6) mendapatkan tanggapan yang beragam. Sebagian besar mahasiwa menjawab interaksi dosen dan mahasiswa berlangsung baik $(42,9 \%)$, sangat baik $(14,3 \%)$, cukup $(14,3 \%)$ dan kurang $(28,6 \%)$. Masih tingginya prosentase kurang pada interaksi dosen dan mahasiswa ini 
perlu menjadi evaluasi dalam pelaksanaan pembelajaran daring.
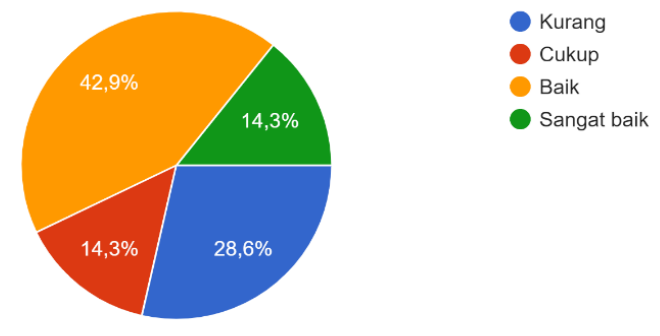

Gambar 6. Interaksi dosen dan mahasiswa dalam pembelajaran daring Sumber: Hasil survey, 2020

Sedangkan tingkat ketertarikan mahasiswa dalam pembelajaran jarak jauh ini adalah sangat kurang tertarik (Gambar 7). Berdasarkan hasil survey, mahasiswa yang kurang tertarik dengan pembelajaran daring sebesar $57,1 \%$, cukup tertarik $28,6 \%$ dan sangat tertarik $14,3 \%$.
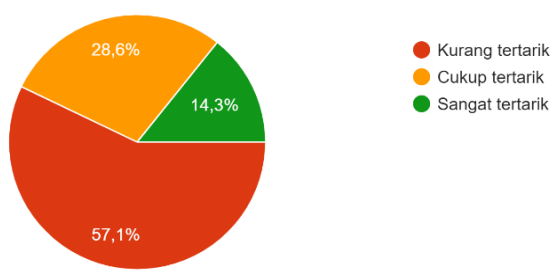

Gambar 7. Tingkat ketertarikan mahasiswa terhadap pembelajaran daring

Sumber: Hasil survey, 2020

Penguasaan atau pemahaman materi kuliah, tutorial dan studio yang disampaikan oleh dosen dalam pembelajaran daring ini adalah kurang (42,9\%), cukup $(42,9 \%)$ dan sangat menguasai $(14,3 \%)$ (Gambar 8).
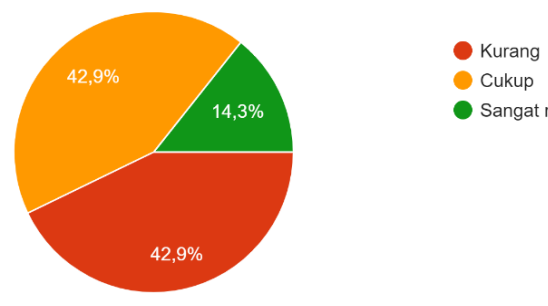

Cukup

Sangat menguasai

Gambar 8. Efektivitas pemahaman materi kuliah, tutorial dan studio Sumber: Hasil survey, 2020
Mahasiswa juga menjawab bahwa kuliah yang paling efektif dalam pembelajaran daring adalah kuliah teori (100\%) (Gambar 9).

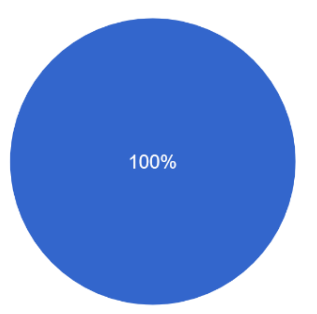

Teori

Gambar 9. Efektivitas mata kuliah Sumber: Hasil survey, 2020

\section{Efektivitas Penggabungan Mata}

\section{Kuliah}

Terobosan-terobosan untuk lebih mengefektifkan pembelajaran daring dilakukan oleh tenaga pendidik Program Studi Arsitektur UPY. Salah satu terobosan yang dilakukan adalah penggabungan proses pembelajaran dua mata kuliah, dimana kedua mata kuliah tersebut mempunyai capaian pembelajaran yang sinergi. Salah satunya adalah mata kuliah Studio Perancangan 02 dan Perancnagan Tapak.

Harapan dari penggabungan mata kuliah ini adalah supaya mahasiswa lebih efektif dalam menerima materi perkuliahan dan juga lebih hemat dalam penggunaan kuota. Berdasarkan hasil survey, hampir semua mahasiswa berpendapat bahwa penggabungan dua mata kuliah tersebut cukup efektif (Gambar 10).
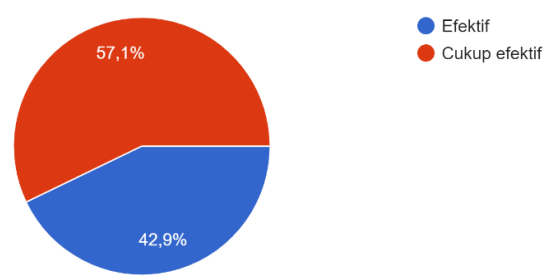

Gambar 10. Efektivitas penggabungan dua mata kuliah

Sumber: Hasil survey, 2020 
Berdasarkan efektivitasnya, hal-hal yang menjadikan lebih efektif antara lain adalah tugas menjadi satu $(85,7 \%)$, materi lebih lengkap $(71,4 \%)$ dan dapat langsung diterapkan pada satu matakuliah (14,3\%) (Gambar 11).

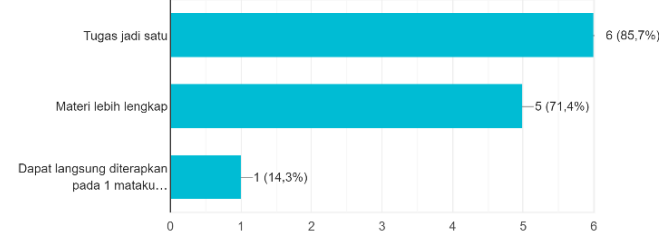

Gambar 11. Faktor yang mempengaruhi efektivitas penggabungan dua mata kuliah Sumber: Hasil survey, 2020

Untuk efektivitas penggabungan dua mata kuliah ini dapat dilihat dari hasil karya mahasiswa yang lebih terarah dan lengkap (Gambar 12).

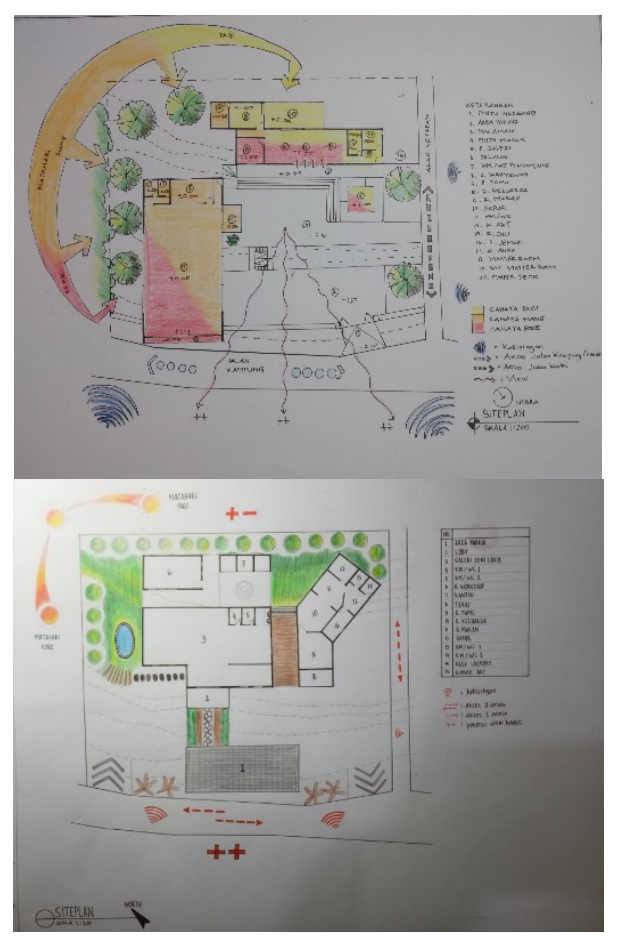

Gambar 12. Contoh tugas mahasiswa mata kuliah Studio Perancangan 02 dan Perancangan Tapak

Sumber: Tugas mahasiswa Prodi Arsitektur UPY, 2020

\section{Jaringan Internet}

Permasalahan teknis jaringan masih menjadi salah satu kendala utama dalam pembelajaran jarak jauh. Berdasarkan hasil survey, $100 \%$ mahasiswa mengalami kendala dalam signal internet (Gambar 13).

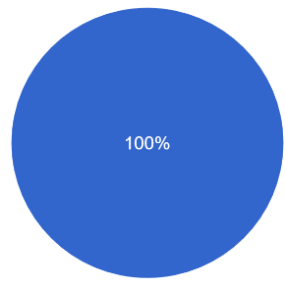

Ada kendala

Gambar 13. Kendala signal internet yang dialami mahasiswa dalam pembelajaran jarak jauh

Sumber: Hasil survey, 2020

Kuesioner berikut ini mencoba menggali berapa besar biaya kuota yang dikeluarkan mahasiswa dalam satu bulan (Gambar 14). Ternyata biaya kuota yang dikeluarkan mahasiswa dalam satu bulan berkisar antara $50-200$ ribu rupiah.

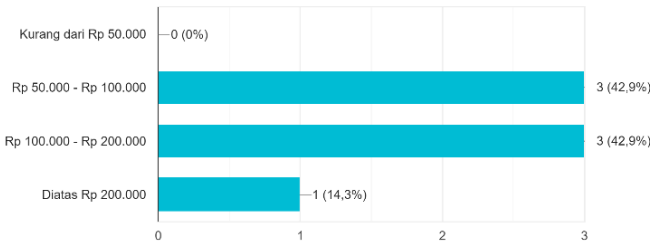

Gambar 14. Biaya penggunaan kuota internet dalam satu bulan Sumber: Hasil survey, 2020

\section{Kesimpulan}

Faktor-faktor yang mempengaruhi belum maksimalnya kesiapan dari pembelajaran daring ini antara lain materi yang disiapkan dosen adalah materi untuk pembelajaran tatap muka, interaksi dosen dan mahasiswa sangat terbatas dan dosen belum terbiasa dalam penyampaian materi secara daring. Selain itu, hambatan jaringan internet juga menjadi kendala dalam 
pembelajaran daring. Penggabungan pembelajaran dari dua mata kuliah yang mempunyai capaian pembelajaran yang sinergi merupakan hal yang efektif untuk metode pembelajaran jarak jauh. Pelaksanaan perkuliah daring memerlukan evaluasi persiapan perguruan tinggi dan juga memerlukan evaluasi dari dosen dan mahasiswa.

\section{Daftar Pustaka}

Jamwal, G. (2012). Effective use of interactive learning modules in classroom study for computer science education. All Graduate Plan B and other Reports, 225. Retrieved from https://digitalcommons.usu.edu/g radreports $/ 225$

Kementerian Pendidikan Tinggi Republik Indonesia. (2020). Surat edaran Direktur Jenderal Pendidikan Tinggi Republik Indonesia nomor 1 tahun 2020 tentang pencegahan penyegaran Corona virus disease (Covid-19) di perguruan tinggi, Kementerian Pendidikan dan Kebudayaan. Jakarta: Kementerian Pendidikan Tinggi Republik Indonesia. Retrieved from

https://covid19.hukumonline.co $\mathrm{m} / \mathrm{wp}$ -

content/uploads/2020/04/surat_e daran_direktur_jenderal_pendidi kan_tinggi_nomor_1_tahun_202 0-2.pdf

Kobayashi, M. (2017). Students' media preferences in online learning.

Turkish Online Journal of Distance Education - TOJDE, Vol. 18, No. 3, Halaman 4-15. DOI https://doi.org/10.17718/tojde.32 8925

Maulana, H.A., Hamidi, M. (2020). Persepsi mahasiswa terhadap pembelajaran daring pada mata kuliah praktik di pendidikan vokasi. Equilibrium: Jurnal Pendidikan, Vol. 8, No.2, Halaman 224-231. DOI https://doi.org/10.26618/equilibri um.v8i2.3443

Oktavian, R., Aldya, R.F. (2020). Efektivitas pembelajaran daring terintegrasi di era pendidikan 4.0. Didaktis: Jurnal Pendidikan dan Ilmu Pengetahuan, Vol.20, No.2, Halaman 129-135. DOI http://dx.doi.org/10.30651/didakt is.v20i2.4763

Sadikin, A., Hamidah, A. (2020). Pembelajaran daring di tengah wabah Covid-19. Biodik: Jurnal Ilmiah Pendidikan Biologi, Vol.6, No.2, Halaman 214-224. DOI

https://doi.org/10.22437/bio.v6i2 .9759

Situru, R.S. (2020). Pembelajaran dalam jaringan (daring) masa pandemic Covid-19. Elementary Journal: Jurnal Pendidikan Guru Sekolah Dasar, Vol. 3, No. 1, Halaman 40-46.

Widiyono, A. (2020). Efektifitas perkuliahan daring (online) pada mahasiswa PGSD di saat pandemi Covid 19. Jurnal Pendidikan, Vol. 8, No. 2, Halaman 169-177. DOI https://doi.org/10.36232/pendidik an.v8i2.458 